\title{
Procurement Process and Its Impact on Development with Special Focus on Nepal
}

Gyawali $\mathbf{B}^{1 *}$ Dahal $\mathbf{K R}^{1}$ and Maharjan $\mathbf{R}^{\mathbf{2}}$

${ }^{1}$ Lumbini International Academy of Science and Technology, Damodar Marg, Manbhavan, Lalitpur, Nepal

${ }^{2}$ Project co-ordination Unit, Ministry of Health, Nepal

\begin{abstract}
The study aims to assess the procurement process and its impact on development projects in Nepal. The method of study was literature survey. The received literatures were analyzed and drawn the conclusions. Public procurement is the major part of development throughout the world. Thus, there is a need for an in-depth knowledge of procurement process as it covers more than $60 \%$ of development activities. The principles of public procurement are: transparency, integrity, economy, openness, fairness, competition and accountability. The study emphasizes that the lack of proper implementation of public procurement process hampers the smooth process of development. Procurement practitioners are the chief actors in this process. Thus, all concern authorities are responsible to achieve the goal. The study found that the improper software, ambiguity in the documents, no tight rules and regulations in the implementation, lack of long term perspective and prepared documents are incomplete in many cases.
\end{abstract}

Keywords: Public procurement process; Transparency; Integrity; Accountability; Public administration

\section{Introduction}

The first law related to public procurement introduced in 1958/59 [1] in Nepal. It addresses the issues such as transparency, competitiveness and accountability and financial administration. It is related to rules and regulation which influences according to time occasion. The financial administration rules 1985/86, 1995/96 and 1999, Public Procurement Act 2063 (PPA) were established in 2007 [2].

Globally, public procurement is a key function and, moreover, it is performed by the government. It directly influences Government performances [3]. The performance of procurement is trustable and reputable duty of ensuring efficient delivery of goods and services to the public sectors [4]. The procurement of goods and services by government and local authorities involves various processes [5]. The public procurement process is different from one country to another because it is governed by procurement laws and regulations. Public procurement may involve in the case of significant amount of demand for goods, services and effective delivery [4]. The government's responsibility to ensure and promote sustainable development with economy and standards of living by utilizing available resources in the most efficient, transparent and ethical manner [6]. The main objective of the public procurement is to minimize cost through maximum competition, transparency, protecting public fund and also reducing and eliminating corruption [7]. However, the implementation and results are mostly affected by the laws governing procurement and also by the socio-political environment, fundamental economic condition and the technological environment of respective countries [8] and most of the studies of public procurement showed, the poor implementation of government projects and service delivery [9].

Nepal, a South Asian country, which lies between India and China. The Gross Domestic Product per capita in the United States was 18624.48 USD Billion, India was 2263.79 USD Billion and in Nepal was 21,132 USD million in 2016 [10]. About $60 \%$ of allocated budget of the government of Nepal has been spending in procurement [11]. Nepal's annul budget (for FY 2013/14) was $\$ 5.17$ billion, among this $46.7 \%$ is allocated development expenditure and $53.3 \%$ regular expenditure [10]. Only $69.6 \%$ of the budget is expected to be met through its own Revenue. But the government is able to make expenditure of less than
$80 \%$ of the allocated budget. The economic growth rate of Nepal is less than 5\%, with major challenges like high inflation 9.9\% [12], foreign depending production system, limited labor market, low physical infrastructure, low institutional capacity and poor governance. This study was conducted during the period of February to April, 2018.

\section{Procurement in Nepal}

Procurement, in general, is an act of obtaining or buying goods and services that includes preparation and processing of a demand as well as the end receipt and approval of payment. Procurement is a purchasing process used to secure services, goods and work from external sources, where external refers organization, company, institution, charity or own person [13]. Large public and corporate organizations participate to promote choice and greater competition with procurement and purchases program [14]. Matthew defines procurement as purchasing of goods, works and service from the supplier and contractor that provide the optimum combination of whole life costs and benefits to meet the customer's requirement. According to procurement law, procurement execute; planning of goods, services and works, prepare cost estimate and procurement plan, select procurement method as per condition of work and budget and invite bidders.

The traditional procurement process is slowly being replaced by E-Procurement. It is web-based buyer and seller who purchase and sell goods, services and works. They collect all necessary data from each other and analyze them. Also, National Electronic-Government Procurement (E-GP) is a web-based procurement portal covering various activities of public procurement life cycle including registration of bidders, procurement planning, e-tendering, on-line evaluation,

*Corresponding author: Gyawali B, Lumbini International Academy of Science and Technology, Damodar Marg, Manbhavan, Lalitpur, Nepal, Tel: 9847180436; E-mail: gyawali.binita01@gmail.com

Recieved June 11, 2018; Accepted July 28, 2018; Published August 03, 2018

Citation: Gyawali B, Dahal KR, Maharjan R (2018) Procurement Process and Its Impact on Development with Special Focus on Nepal. J Entrepren Organiz Manag 7: 243. doi: 10.4172/2169-026X.1000243

Copyright: ( 2018 Gyawali B, et al. This is an open-access article distributed under the terms of the Creative Commons Attribution License, which permits unrestricted use, distribution, and reproduction in any medium, provided the original author and source are credited. 
contract award and management etc. These processes used as solution for indirect purchases, tendering and other different task related to procurement [2].

According to PPA (section 64), the authorized body of procurement process (planning to implementation and handover) in Nepal is Public Procurement Monitoring Office (PPMO). It was established under the Office of the Prime Minister and Council of Ministers (OPMCM) in August 20, 2007. The Government of Nepal (GON) decided about PPMO operation. Accordingly, PPA function and duties of PPMO are to:

- Generate required recommendations to the GON to reform policies/laws related to procurement and published technical guidelines and its manuals,

- Prepare standard bidding documents, prequalification document, and contract document and help to conduct procurement proceeding,

- Create procurement websites and conduct the procurement training programs,

- Submit the annual report of the procurement proceedings to the GON,

- Monitor the public procurement activities and give the directions to the public sectors,

- Design simple and easy way to procurement processes and

- Establish a central data bank and maintain record of procurement contract implementation performances.

Public procurement was a challenge for PPMO to guide all the public entities into standard procedures of procurement giving various conflicts and interests in the beginning. But PPMO has covered all reasonable value and credit of having a single legislative instrument in the country for last five years. It has started regular programming in 2010 to provide the successful program delivery prepared by Nepal Public Procurement Strategic Framework (NPPSF) Phase I which was applied from 2010 and it provides reasonable achievements. In 2013, second programming cycle NPPSF Phase II was established.

The Phase II programming process updated from previous phase as it was prepared after learning lessons from the NPPSF phase I. All required documents are prepared under the guidelines of PPMO with the support of World Bank during formulations of phase II. Numbers of workshops were held to define priority issues, problems and guidance for effective delivery of the program. It provides a guideline to handle variety of enterprises and seek resources and finance during its program implementations [2].

Public procurement affects large share of government budget and people's lives. So, it is the main concern of government to obtain and raise the efficiency, transparency and effectiveness. As large volume of annual budget used for procurement process, it plays vital role in economic growth [15]. Hence, improvement in Public Procurement can expand financial governance in the country [16].

\section{Principles of procurement}

Raymond and Adhikari [1,17] defined five key principles related to procurement. These are: value of money, ethics, competition, transparency and accountability.

Value of money: The most important and valuable principle of procurement is value of money [17], her Majesty's treasury in the UK defined as "the optimum combination of whole-life costs and quality or fitness for purpose to meet the user requirement" [18]. Quality standards are maintained by evaluating cost and benefits of whole life basis including a judgment of risk to all stakeholders. In construction sector, value for money is very important factor but difficult to maintain specially in public sector due to lack of universal methodology to follow [19].

The minimum value of cost should not be taken in value of money [20]. But in some countries lowest quoted price is prioritized than other criteria (for example, technical capabilities, experience and past performance records, qualifications of key personnel) in awarding contracts to respective suppliers [21]. The main barriers which lead to hamper the value for money are weak governing bodies, traditions, improper plans, politics, and lack of awareness and training programmers [22].

Ethics: According to Raymond [17] ethics is another important principle of procurement after value of money. It is a systematic manner to construct sense of all individual and social moral experience with all human conduct rules [23].

Purchasing professional requires higher standards of ethical conduct with professional awareness than other professions [24], A research has shown that out of 500,000 professional purchasing people in America only 10 percent have been members of a professional Supply Chain Management Association while the rest are not even aware that there are ethical and legal standards involved in procurement. Procurement related corruption is the major problem in developing countries [17]. The writer also suggests that the main cause of corruption in these countries is due to poverty. Also, there is a weak enforcement of the law in these countries. Thus, some measures are needed to control the corruptions.

Competition: Competition in procurement is a most essential part to maintain the quality, cost and time. Raymond [17] defined that competitive tendering is a critically secured in case of purchasing goods as well as services. The author recommended that in this competitive process there is trustworthiness of all the bidders, prices are compared between the bidders and finally most competitive and suitable bidder is awarded with the tender. The tender notice is the most important source of information for all suppliers and bidders [25]. According to Erridge et al. [25] wrong data and lack of complete information in the tender notice create misunderstanding and increase cost. So, qualitative information in notice is most essential part of tender. It is believed that competitive tendering helps to avoid fraud and unfavorable condition of competition and reduce prices and increase quality. The procurement rules help in creating competition in markets and improve quality [17]

Transparency: The function of transparency is a significant part of procurement and it shows openness [17]. The transparency helps to ensure accountability and reduce corruption and gives importance to Organizations for Economic Cooperation and Development (OECD) and raise the objectives of government as core governance value [26]. Government procurement is an area where corruption is uncontrolled in most developing counties [17]. According to Smith [26] transparency requires governments to stick higher standards of performance and ensuring that performance to be open to survey. The transparency of the procedure used in awarding contracts and agreement to the supplier is challenging due to interference created by officials and political parties [27]. Construction procurement also requires transparency in the public and private sector to provide a commitment 
for both domestic and foreign investors where contract will be awarded in an honest and fair manner [17]. In other sectors, due to lack of transparency regarding rules and practices can create a barrier to trade and affect foreign suppliers than locals [18]. Transparency system helps to reduce the cost and get goods and services in a cheaper price [17]. Transparency promotes trust and confidence between stakeholders and judge the quality of government actions and decisions [26]. Nowadays, transparency is an increasing demand worldwide and corruption is very strongly controlled in awarding government contracts [28]. Hence the transparency in procurement helps in corruption control [27].

Accountability: In both national and international levels, accountability is important for government procurement [17]. It states that at the national level public sector, managers should deal more competitive environment. The complex competitive environment associated with risk may elevate accountability problems [29]. The main reason of accountability problem is due to unclear roles and responsibilities of the participants in the process of procurement [17]. The concept of accountability should apply both in public and private sectors to provide better services $[29,30]$. Procurement also includes other different issues such as "culture, leadership, management, and economy, environment, ethics and politics" [31].

\section{E-procurement}

E-procurement has a specific feature which is carried out by internet [32]. Davila et al. [33] defines e-procurement technologies as the facilitation in the acquisition of service, goods, and works over the internet. A successful company requires good internet facility and its management to hold the competitive supply chain. The major aim of E-procurement is to run the procurement process smoothly to have an efficient supply chain [33]. The procurement is a significant activity in all types of organization [34]. It is one of the largest expenses items in a company's cost structure and it can influence overall performance of that company. And procurement manager tries to decrease the procurement cost by using e-procurement [35]. E-procurement has different classification with different application [36]. According to De Boer et al. [37] e-procurement has six forms; E-MRO, Web-based ERP, E-sourcing, E-tendering, E-reverse auctioning and E-informing.

In the context of Nepal, World Bank's new procurement Framework was approved by WB Board on July 21, 2015 to modernize the procurement policy and maximize the strategic role of procurement in attaining key development goals making it is mandatory for all lending operations after July 1, 2016 [36]. The new Framework emphasizes flexibility, quality and greater value for public expenses.

While empowering modification to country contexts. PPMO Phase II (2013-2016) adopted a strategic policy for implementation of national e-GP system. The national e-GP modules are primarily interactive module of public entity, bidder and banker and secondary is, public procurement management information system (PPMIS) user, PPMO and oversight module [2,38]. PPMO is provided with authority to operate single national e-GP portal to carry out the procurement process in 2011.The development of e-GP Phase II completed in December 2015 and it was rolled out from 1 January 2017 to all the public entities across the country including all local level agencies fulfilling all rules of procurement from planning to implementation [39].

To make the e-GP System secure, strong and powerful, independent security assessment has already been carried out by Office of the Auditor General, Department of Information Technology, e-GP international expert and the system developer. To build the confidence and increase connection with the system, 54 training sessions and trained around 1600 personnel from public entities, bidding community and banks have been involved in the system. All necessary infrastructures require for e-GP have been set up with all services needed. The functions of e-GP System are: Registration of Stakeholders; Public entity registration, bidder registration, bank registration and report users for oversight agencies [39].

\section{Process of procurement}

Procurement is the process of implementing planning and hiring the contractor, supplier, consultant or service provider for concerned job. Public procurement act (PPA) and regulation (PPR) in 2007 was published to make the procurement system transparent, competitive, fair, accountable and reliable in public procurement process providing equal opportunity to the bidder without any discrimination [15]. After the establishment of procurement unit; PPMO instructed all the public entities for effective public procurement. The district treasury control offices have been taking all authority of PPMO to monitor and establishment of procurement units (Figure 1).

Selection of procurement method and contract: Public procurement process is different according to the nature of works, goods and services; it includes in general the followings:

- Procurement of goods, works and services:

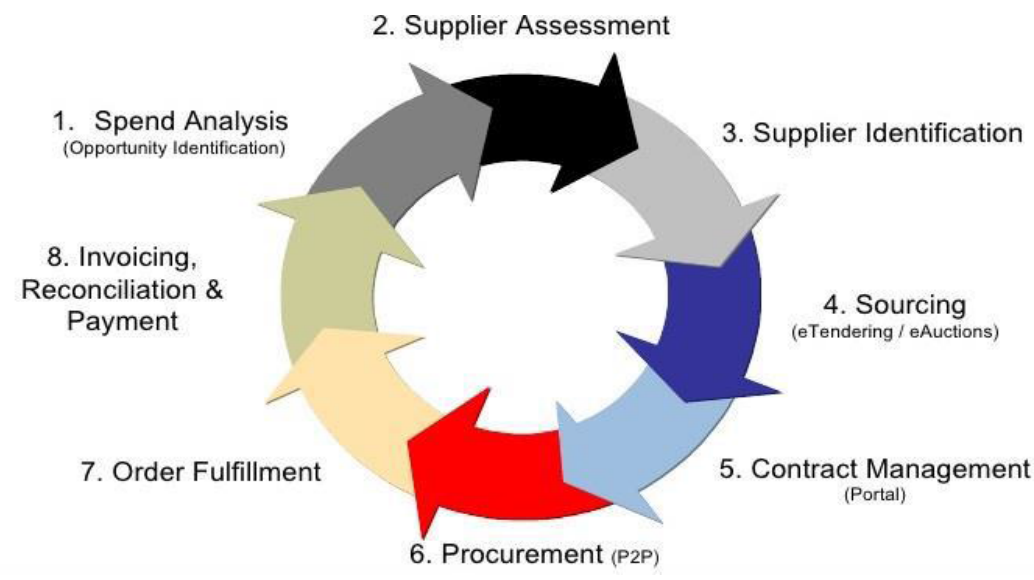

Figure 1: Shows the basic procurement process. 
Sealed Quotation, Direct purchase, User committee or beneficiary groups and Force account

\section{- Procurement of consultancy services:}

Competitive proposal and through negotiation.

Provision related to tender: Single stage and two- stage bidding system as per PPA (sub-section 28.1) [2]; inviting open and close bid by determining pre-qualification and without determining prequalification.

\section{The stages of bid examination and evaluation are:}

Stage 1: Examination of legal requirement:

- Analysis of certificate related to firm, origination or company registration,

- Analysis of business registration certificate; with license as per construction business Act 2055 (1999),

- Analysis of value added tax (VAT) and permanent account number (PAN) registration certificate,

- Analysis of Tax clearance certificate,

- Declaration by bidder; the bidder is qualified to take part in the procurement, no conflict of interest and has not been punished for any offenses and

- Any other requirement if needed.

Stage 2: Examination of completeness of bids:

- Detailed examination of first stage document based on place, date, period, type and amount,

- Authorized Power of Attorney,

- Joint venture agreement in case of JV,

- Eligibility of the bidder,

- Qualification of the bidder,

- Valid rate analysis and

- Additional documents as per bid document.

To control the corruption and unscrupulous competition, the cartel system should be controlled in public procurement process [40]. To make more competitive and transparent, political involvement should be controlled, e media participation, should be increased, information system should be improved, and lack listed bidder should be controlled.

Stage 3: Evaluation of technical aspects:

The evaluation committee analyses the following aspects:

- Scope of job (supply of goods, works and services),

- Technical specification of key items of goods, works, services and performance characteristics and

- Duration of valid warranty period.

Stages 4: Evaluation of commercial aspects; as per sub rule 63.1 [2] of PPR:

- Period of supply or completion of goods services and works,

- Terms of payment,

- Payment based on liquidated damages for the failure of work or delay of work and bonus receivable for the early completion of the work,

- Guarantee obligation of the bidder,

- Obligation of performance by the bidder and

- Other terms as mentioned in bid document.

Stage 5: Evaluation of financial aspects:

- The domestic goods and local construction entrepreneur are to be adjusted if the preferences for them are to be given in these stages.

Stages 6: Special evaluation of bids for construction works:

As per (sub rule 65.1 of PPR), Following works are evaluated:

- Plan of construction work, performance schedule, and mobilization time,

- Examination of reliability of per unit rate quoted in bill of quantities, and

- In lower convincing price, extra performance cost is considered for the validity of quoted price.

Stage 7: Determination of lowest evaluated bid

- PPMO has clearly guided that the bidder cannot be awarded with contract only on the basis of low bid. Lowest bidder (very low bidder) can be accepted only after satisfactory clarification given but he has to provide additional 8 percent performance security [41].

Stage 8: Post-qualification examination

- The lowest evaluation bid is examined depending upon the bid document and it should meet all the qualification mentioned.

Stage 9: Preparation and submission of bid evaluation report

- This is a final stage of tender evaluation. In this stage the committee prepares detailed Bid Evaluation Report (BER) which is finally submitted to the concerned public entity.

Contract management: The contract management includes various aspects from the very beginning of the project to its end. Work schedule update, progress report generation, submission/acceptance of bidder, defining payment milestones for goods, running bill payment processing, variation order, work completion certificate, final payment and dispute handling are the scope of contract management. PPMO has been monitoring all this activities since its establishment. PPMO has the following features for the management of all the projects:

Bank verification: The verification of Bid document purchase fee, Bid Security and Performance Security are done through Banking Interface with PPMO.

- Bank has been supporting PPMO to handle security Extension, release.

Public procurement management information system (PPMIS): Compliance monitoring through key procurement performance indicators

- Manage (Management Information system) MIS reports.

System and security administration: Provision of Bid Encryption/ Bid Decryption, and 
- $\quad$ Provision of SSL Certificate/One Time Password (OTP).

Application usability and help: E-mail notification for key transactions.

- Dashboard for all users.

- $\quad$ E-Government Procurement Directives, and

- $\quad$ Manuals for all users.

\section{Advantages of e-procurement}

The implementation of E-Procurement is an effort to improve the procurement goals with better quality, time management, cost reduction, financial and technical risks minimization and maximization of competition [42]. The conversion from paper-based to e-purchasing can reduce overall time and cost, saving administrative cost as well [43]. For the coming days electronic system offers all the advantages of e-procurement and every industry accepts it. The reduction of paperwork, less errors, easy recording, original information, and easy inventory management with quicker delivery times with advance technology is beneficial to every user for successful implementation of the project. The proper use of internet-based technology is more beneficial and provides a competitive advantage [44]. It also helps firms quickly procure in lowest price, increase global market, fast communication, reduce geographical barriers, and maintain sound relationship between clients and bidders [45]. And According to Min [46], key E-Procurement benefits are:

- Cost savings and subsequent increase in return-on-investment,

- Enhancement of supply chain efficiency by providing real-time data regarding product availability, inventory level, shipment status, production requirements,

- Facilitation of collaborative planning among supply chain partners by sharing data on demand forecasts and production schedules that guide supply chain activities and

- Effective linkage of customer demand information.

According to Public Procurement in Nepal [39], benefits of e-GP system are;

- Minimized collusion and intimidation, insecurity and improved transparency,

- Reduced turn-around time of procurement cycle and improved process efficiency,

- Easy access of national and international bidders in procurement,

- Procurement information (PPMIS) - easy monitoring and analysis and effective decision making,

- Improved regulatory compliance and

- Consolidated database of Contractors/Suppliers/Consultants profile helps in future to monitor bid capacity.

Procurement is a major part before starting any type of development work to ensure a desired level of sustainable economic growth in any developing countries. Effectiveness of procurement is difficult to determine and report during project evaluation and reporting. Process such as acquisition, purchasing, logistics, monitoring, quality assurance and contract administration are involved in e-procurement [47].

\section{Challenges of e-procurement}

The main issues of e-procurement process are lacking due to unskilled resources, poor knowledge of technology, ambiguity in rules and criteria for implementation of bidding evaluation and lack of software handling by user.

According to Davila et al. [33] there are major four risks associated with using E-procurement, which are:

- Internal business risks: While using E-procurement the user is not careful in the field of accounting, human resources, account payable and cost management.

- External business risks: IT infrastructure needed for suppliers to do E-procurement.

- Technology risks: There are different phases of E-procurement so it is creating ambiguity to companies while working.

- Process risks: E- procurement process is completely based on new technology and peculiar software. So, there must be skilled manpower to use it.

The main risky factors are hacking, viruses, pirating, illegal trading, fraud, money laundry, defamatory libel due to electronic transactions carried out in internet. So, they negatively impact on trust, clarity and transparency in tendering [48].

According to Angeles and Nath [49] e-procurement implementation has some challenges as follows:

- System integration and standardization issues are very poor,

- Weakness of supplier in his preparation and solution. There is immaturity in providers while using of E-Procurement services and

- Difficult to implement new system immediately in market.

According to Adhikari [1], related problems of procurement in Nepal are:

Political instability, weak implementation of rules and regulation, weak public administration, low accountability, corruption, lack of proper knowledge of procurement documentation, inappropriate staff transferring, weak software and its handling, narrow vision, interference of the politicians and lack of decision making power are the major problems of e-procurement. For example, in six years period of the operation PPMO was led by six different leaders (from August 20, 2007 to August 19, 2013) [50]. Due to weak evaluation system and discretionary power of the government to transfer and promote the staff, it has hampered in implementing the work [51]. Government projects are highly affected by high political interventions, insufficient number of staffs in government institutions, excessive expenditure in training and lack of knowledge in new transferred staff. Many unexpected problems can be prevented by experienced and skilled staff than a new and inexperienced one in public procurement process [50].

Before starting procurement planning, government progress and budget are required for identification and formulation in any projects. In Nepal, the yearly budget does not meet by its own revenue. The revenue is estimated to contribute $71.5 \%$, foreign grants $11.6 \%$, principle repayment $1.1 \%$ and foreign loan and domestic borrowing $15.8 \%$ to the government's total expenditure. Every year, the repayment of principle and interest against public debt is $10 \%$ of government's 
total expenditure and the foreign debt and total outstanding debt stands $58.6 \%$ [52].

National planning commission is the authorized body to approve the progress submitted by the concerned ministry and the ministry of finance releases budget. A national pride project - Kaligandaki corridor $(417 \mathrm{~km})$ has faced a budget crunch [52] but in April 2018, 10 crore budgets is added by the government for its further progress. There is a record of reallocation of budget for the already completed project [52]. According to the report of the Office of the Auditor General (OAG), all budget allocated for national projects are not developed and spent as expected [53]. It showed that there was no proper vision and homework to analyze and allocate budget.

There are some cases of project failure in Nepal [Table 1]. The major causes of project failure are unprofessional and improper use of project planning and scheduling, also lack of users input incomplete requirement, lack of executive support, lack of technology and lack per defined rule due to fraud activities, unethical and unprofessional practices [11] Human Development Index (HDI) 0.548 and its rank is 145, according to Human Development Report 2015 [57]. According to Public Expenditure and Financial Accountability [58], in any project, expenditure to original approved budget varies. The ability to implement the budgeted expenditure is a major factor in supporting the government's ability to deliver public services. The ratio of actual expenditure to approved budget is as follows [58]:

- $\quad$ FY 2003/04=94.12\%,

- $\quad$ FY $2004 / 05=99.81 \%$, and

- $\quad$ FY $2005 / 06=94.44 \%$.

In Nepal, it is estimated that $60 \%$ of government expenditure is allocated to public procurement, which is significant for a country that is covering liquidity challenges coupled with a lack of balance of payment support [59].

\begin{tabular}{|l|l|l|}
\hline Descriptions & Simple Reasons & Complex Reason \\
\hline Poorly managed & Undefined project objectives and goals & Lack of management commitment \\
\hline Lack of a solid project plan & Lack of user input & Lack of organizational support \\
\hline Centralized proactive management initiatives to combat project risk & Enterprise management of budget resources & Provides universal templates and documentation \\
\hline Poorly defined roles and responsibilities & Inadequate or vague requirements & Stakeholder conflict \\
\hline Team weaknesses & Unrealistic timeframes and tasks & Competing priorities \\
\hline Poor communication & Insufficient resources (funding and personnel) & Business politics \\
\hline Overruns of schedule and cost & Estimates for cost and schedule are erroneous & Lack of prioritization and project portfolio management \\
\hline Scope creep & No change control process & Meeting end user expectations \\
\hline Ignoring project warning signs & Inadequate testing processes & Bad decisions \\
\hline
\end{tabular}

Table 1: Challenges of e-procurement.

of resources [54]. There are many causes of project delay, among them some are; delays in procurement process, unclear policies and objectives, weak institutional capabilities, defective project design, delays in project approval, delay in budget release, poor monitoring and evaluation system and corruption [55]. Most of the projects are failing due to improper plan and wrong estimate also fail in implementing phase by human error [56]. Procurement planning is depended on cost estimation of project, specification of items, terms and conditions of bid documents, project schedule, preparation of bidding document and selection of the procurement method [1]. Thus, to avoid effect from public procurement identification and formulation of the project on the basis of real need, well preparation of procurement plan by skilled and experienced human resources. As per the provision of PPA [2], the contract having duration more than 12 months requires price adjustment. This project time is not more than 12 months to avoid the price adjustments.

As defined by PPMO, the major issues of traditional public procurement system in Nepal are: efficiency, transparency, competition and value for money, quality degradation, time and cost overrun, inadequate capital and poor monitoring and contract management [2]. A huge number of procurement of goods, services and work are going on indicating the pace of development in the country. There are inadequate experienced human resources which is leading difficulties in its effective implementation.

Some e-GP related difficulties are (according to PPMO staffs):

- $\quad$ Limited technical person, less knowledge of e-GP process in local level entities, lack of bidders to handle antiviruses and browser, knowledge about procurement technology and software package.

\section{Relationship between procurement and development}

Countries like Nepal where procurement process can't upgrade as

\section{Conclusions}

Procurement process, indeed, is difficult in handling and implementing projects. Various negative factors like improper software, ambiguity in the documents, no tight rules and regulations in the implementation, lack of long term perspective, incomplete documents etc. are the reasons to create negative impacts. The unnecessary political interest in the procurement process is also the complication. These negative factors lead to delay and smooth running of the projects which ultimately hampers the development process of the nation.

The poor practice of budget planning and its timely release during implementation by the concerned authority ruin the whole project. The planning done by procurement practitioners, who are chief actors in this process, are responsible to achieve the goal. However, it is lacking with procurement practitioners.

\section{Acknowledgements}

We would like to acknowledge procurement monitoring officer, Shikendra Kumar Jha, Dr. Nar BikramThapa, Sushila Aryal and Anoj Dhungana for their contribution during preparation of this paper.

\section{References}

1. Adhikari RP (2015) Public Procurement Issues and Challenges in Nepal. Journal of Engineering Economics and Management 2: 3-27.

2. Public Procurement Monitoring Office (2017) Government of Nepal Office of the Prime Minister and Council of Ministers.

3. United Nations Development Program/Inter-Agency Procurement Services Office (2006) Sustainable Procurement Guidelines: Economic, Social and Environmental Considerations in Public Procurement, University of Salford, Manchester, United Kingdom.

4. Uyarra E, Flanagan K (2010) Understanding the Innovation Impacts of Public Procurement. Eur Plan Stud 18: 123-143. 
Citation: Gyawali B, Dahal KR, Maharjan R (2018) Procurement Process and Its Impact on Development with Special Focus on Nepal. J Entrepren Organiz Manag 7: 243. doi: 10.4172/2169-026X.1000243

5. Roodhooft F, Abbeele AVD (2006) Public procurement: Consulting Services Evidence and Comparison With Private Companies. International Journal of Public Sector Management 19: 490-512.

6. Seidu SS, Fatawu A, Ahmed S (2014) Assessing the contribution of Public Procurement in revenue mobilization in Ghana. IJECM 2: 1-20.

7. ADB/OECD (2008) Fighting Bribery in public procurement in Asia and the Pacific: Proceedings of the 7th Regional Seminar on Making International AntiCorruption Standards Operational: Asian Development Bank/Organization for Economic Cooperation and Development Anti-Corruption Initiative for Asia and the Pacific, Indonesia, pp: 1-247.

8. Gayed YEL (2013) The Influencing Factors of Public Procurement Policy Development-The Case of Libya.

9. Tsabora J (2014) Public Procurement in Zimbabwe-Law Policy and Practice. APPLJ 1: 1-21.

10. World Bank (2018) United States GDP per capita (1960-2018) Data Chart Calendar.

11. Gerardino MP, Litschig S, Pomeranz DD (2014) Monitoring Public Procurement: Evidence from a Regression Discontinuity Design in Chile.

12. Nepal's Per Capita Income Crosses 1,000 USD In 2017-18 Fiscal Year.

13. Dalkin FJ (2014) Definition - What is Procurement?

14. Kalubanga M (2012) Sustainable Procurement: Concept, and Practical Implications for the Procurement Process. IJEMS.

15. Public Procurement Monitoring Office (2013) Nepal Public Procurement Strategy Framework, Phase II (2013-2016).

16. Ministry of Finance (2010) Nepal Portfolio Performance Review.

17. Raymond J (2008) Benchmarking in Public Procurement. Benchmarking Int $J$ 15: 782-793.

18. Arrow smith S (2003) Transparency in Government Procurement: The Objectives of Regulation and the Boundaries of the World Trade Organization. J World Trade 37: 283-303

19. Bauld S, McGuinness K (2006) Value for money. Summit 9: 20-21.

20. Pitt M, Collins N, Walls A (2006) The Private Finance Initiative and Value for Money. J Property Invest Finance 24: 363-373.

21. Cummings G, Qiao Y (2003) The Use of Qualification-Based Selection in Public Procurement: A Survey Research. Journal of Public Procurement 3: 215-249.

22. Palmer RD, Butt AH (1985) Value for Money in the Public Sector. The Decision Makers Guide, Basil Blackwell, Ltd, Oxford.

23. De George RT (1990) Business Ethics. Macmillan Publishing Company U.S.A.

24. Atkinson W (2003) New Buying Tools Present Different Ethical Challenges. Purchasing 132: 27-30

25. Erridge A, Fee R, Mcllroy J (1999) An Assessment of Competitive Tendering Using Transaction Cost Analysis. Public Money and Management 19: 37-42.

26. Smith-Deighton R (2004) Regulatory Transparency in OECD Countries: Overview, Trends and Challenges. Aust J Publ Admin 63: 66-73.

27. Rege V (2001) Transparency in Government Procurement: Issues of Concern and Interest to Developing Countries. J World Trade 35: 489-515.

28. Rothery R (2003) China's legal framework for Public Procurement. Journal of Public Procurement 3: 370-388.

29. Barrett $P$ (2000) Balancing Accountability and Efficiency in a More Competitive Public Sector Environment. Aust J Publ Admin 59: 58-71.

30. Gunasekaran A (2005) Benchmarking in Public Sector Organizations. Benchmarking Int J 12: 289-292.

31. Walker Dht, Rowlinson S (2008) Procurement Systems - A Cross Industry Project Management Perspective. Taylor \& Francis, London.
32. Versendaal J, Brinkkemper S (2003) Benefits and Success Factors of BuyerOwned Electronic Trading Exchanges: Procurement at Komatsu America Corporation. JITCA 5: 39-52.

33. Davila A, Gupta M, Palmer R (2003) Moving Procurement Systems to the Internet: The Adoption and Use of E-Procurement Technology Models. Eur Manag J 21: 11-23.

34. Croom SR, Johnston R (2003) E-service: Enhancing Internal Customer Service through E-Procurement. IJSER 14: 539-555.

35. Trkman P, McCormack K (2010) Estimating the Benefits and Risks of Implementing E-Procurement. IEEE Transactions on Engineering Management 57: $338-349$.

36. Knudsen D (2003) Aligning Corporate Strategy, Procurement Strategy and E-Procurement Tools. Int J Phys Distr Log 33: 720-734.

37. De Boer L, Harink J, Heijboer G (2002) A Conceptual Model for Assessing the Impact of Electronic Procurement. Eur J Purch Supply Manag 8: 25-33.

38. Sharma RK (2016) Implementation of National e-GP System in Nepal. The World Bank Procurement Framework.

39. Public Procurement Monitoring Office (2018) Brief e-GP Bulletin Published on the Occasion of 7th Anniversary of PPMO, 2013/8/9, Kathmandu, Nepal.

40. Bhattarai P (2011) Republic of 1.3.2011

41. Public Procurement Monitoring Office (2014) Yearly Report of the Public Procurement Monitoring Office 2070, Kathmandu, Nepal, pp. 28-29.

42. Thai KV, Grimm R (2000) Government Procurement: Past and Current Developments. Journal of Public Budgeting, Accounting and Financial Management 12: 231-247.

43. Brack K (2000) E-Procurement: The Next Frontier. Industrial Distribution 89: 65

44. Attaran M (2001) The Coming Age of Online Procurement. Ind Manage Data Syst 101: 177-181.

45. Gunasekaran A, Marri HB, McGaughey RE, Nebhwani MD (2002) E-Commerce and Its Impact on Operations Management. Int J Production Economics 75 185-197.

46. Min H, Galle WP (2003) E-Purchasing: Profiles of Adopters and Non-Adopters. Ind Market J 32: 227-233.

47. Stukhart G (1995) Construction Materials Management. Marcel Dekke, USA.

48. Darlington R (2006) Crime on the Net

49. Angeles R, Nath R (2007) Business-to-business E-Procurement: success factors and challenges to implementation. IJSCM 12: 104-115.

50. Public Procurement Monitoring Office (2013) Yearly Report, 2069, Kathmandu, Nepal.

51. Tharu BM (2002) Causes of Project Failure in Nepal. Master in Sustainable Development Kathmandu University.

52. Ministry of Finance (2013) Economic Survey Fiscal Year 2012/13.

53. Awale S (2016) Delays-National-Pride-Projects-Set-Poor-Example.

54. Toader CS, Brad I, Adamov TC, Marin D, Moisa S (2010) The Main Cause Which Lead to Success or Failure of a Project. Scientific Papers: Animal Science and Biotechnologies.

55. Agrawal GR (2006) Project Management in Nepal. Kathmandu: MK Publishers pp: 10-16.

56. Coley P (2007) Why Projects Fail? Project Fail.

57. UN (2015) Nepals-HDI-Ranking-Improves-Moderately-to-145-UN

58. PEFA Public Expenditure and Financial Accountability (2008) An Assessmen of the Public Financial Management Performance Measurement Framework.

59. Pant U (2017) Public Financial Management Reforms in Nepal. 